\title{
THE TRANSITION FROM INFORMATION MANAGEMENT TO KNOWLEDGE MANAGEMENT THROUGH ACTIVITY - BASED APPROACH
}

\author{
S. Burak ARZOVA \\ Marmara Üniversitesi, Sosyal Bilimler M.Y.O., Yardımcı Doçent Dr.
}

\begin{abstract}
Özet: Günümüzde en önemli gü̧̧ bilgidir. Ancak gelişen bilgi iletişim araçlarn, bu araçlara ulaşmadaki kolayltk, bilgiye sahip olmak için gereken mekan ve zaman kavramlarinda da değişiklik yaratmıştr. Bu nedenle salt bilgiye sahip olmak arthk güçlï olmak için yeter şart değildir. Bilgi, bilgiden fayda yaratacak olan kişilere iletilemediği sürece, toplama, sinfflandirma ve özetleme aşamalarina harcanan zaman dolayısıyla bir külfet olmaktan öteye gidemeyecektir. Bu nedenle gelişen șartlar, bilginin iyi yönetilmesini gerekli ktlmaktadır. Yeni literatürde, bilgi yönetiminin bir üst dïzeyi olan bilebilirlik yönetimi kavramı karşımıza çıkmaktadır. Bu çalışmada; işletmelerde katma değer yaratmayan her tïrlï faaliyetin elenmesine yönelik çalsşmalan kapsayan faaliyet tabanlt yaklaşımın, bilgi ve bilgi yönetiminden, bilebilirlik yönetimine geçiş aşamasında nastl kullantlacağı konusu üzerinde durulmuştur.
\end{abstract}

\section{INTRODUCTION}

In their pursuit of customer, management must ensure that the product or service output of their firm meets the demands of the market. To achieve this they should consider their organization's ability to deliver appropriate products and services, at the time when they are wanted, of a standard and quality that is expected, and at a price which is competitive. These objectives require balancing, as there are distinct trade-offs among them. Underlying them all, however, is the question of their cost. Strategies, policies and actions in respect of these factors will need to take account of the cost implications and indeed may involve establishing new requirements for various aspects of the business. These are the basic ingredients of cost management. To be effective, cost management must be based on a sound knowledge of the organization's cost structure and an appreciation of how costs are determined and therefore how they may be influenced. This understanding assists managers in exerting effective control over costs in pursuing their objectives. However, knowledge requires information [1].

Management accounting consists of accounting techniques and procedures for gathering and reporting financial, production, and distribution data to meet management's information needs. The management accountant is expected to provide timely, accurate information. The information that management accountants gather and analyze is used to support the actions of management. All business managers need accurate and timely information to support pricing, planning, operating, and many other types of decisions. Managers of manufacturing, merchandising, government, and service organizations all depend on management accounting information. Multidivisional corporations need large amounts of information and more complex accounting and reporting systems than do small business. But small - and medium - sized businesses make use of certain types of financial and operating information as well. The types of data needed to ensure efficient operating conditions do not depend entirely on an organization's size [2].

\section{THE DIFFERENCES BETWEEN INFORMATION MANAGEMENT and KNOWLEDGE MANAGEMENT}

As information technology evolves, organizations will increase their effectiveness. Further more, as markets change, companies and organizations will run into global competitors that increasingly look to information and information technology for competitive advantage [3].

A total transformation in the economics of business is the root of the revolution of management control systems. We are hurrying away from the traditional economies of mass production to the economies of "mass customization", using flexible processes and work forces to provide variety of low cost. In this new world all the management controls that drive people's behavior are being rethought - accounting, manufacturing process controls, compensation, and related performance measurement systems. The boundaries between these areas are evaporating. The classic example is quality control [4]. 
Defining data, information and knowledge is difficult. Only through external means or from a user's perspectives, can only distinguish between data, information, and knowledge. In general, data are considered as raw facts, information is regarded as an organized set of data, and knowledge is perceived as meaningful information [5].

Information highway should be viewed as more than a high-speed mechanizing force; it can fundamentally reshape the way business is done. The effective us of information and communication technologies in the information highway age enhances competitive advantage by [6]

$\checkmark$ delivering increased productivity;

$\checkmark$ reducing both product development and marketing life cycles; and

$\checkmark$ facilitating redesign and re-engineering of the workplace.

Zoikoczy defines information "as the meaning that a human expresses by, or extracts from, representations of facts and ideas, by means of the known conventions of the representations used" [7]. This definition includes the word "meaning" which is just intangible and elusive as "information". As a concept, information is the raw material for making decisions for creating knowledge and fuelling the modern organization and has always connoted different meanings to various information professionals, depending on what side of the information profession they belong [8].

Like energy and politics, technology is changing the ways in which information is captured, processed, stored, disseminated and used. Information, therefore, like any other resource in an organization, should be properly managed to ensure its cost-effective use. It is an ingredient that is vital to good management and if properly managed, should rang in importance with the organization's personnel, material and financial resources. In an organizational context, it is increasingly being recognized as a resource independent of the technology using in manipulating it [8].

It is now said that value added in most businesses today is in the form of knowledge, not "stuff". The extended IT industry has been quick to promote the notion that knowledge management not only lowers cost structures and increases strategic flexibility but also facilitates knowledge creation and utilization, especially in firms competing in dynamic environments. Knowledge involves thinking with information. If only the circulation of information is enabled, knowledge is not thereby increased. Finding who knows what in an organization has always been time-intensive. Thus, a knowledge management system must include a way to find people based on their skills and area of expertise [9].

There should be distinct but integrated strategies for both information systems and information technology. Both should be part of the of the overall business strategy considerations. Clearly the role of information technology is to support operational and information systems, which in turn are to support decision-making activities at all level of management. As such we can view information technology function as "supplying" to the "demands" of information systems functions which in turn "supply" to the "demands" of management. A cycle of activities should be led by the business strategies influencing the information systems function: this in turn indicates its needs and priorities to the information technology function which rationalizes and supplies appropriate infrastructures and services [10].

Information management has been defined as the organization - wide capability of creating, maintaining, retrieving and making immediately available the right information, in the right place, at the right time, in hands of the right people, at the lowest cost, in the best media for use in decision making [11].

Knowledge management systems must connect people to enable them to think together and to take time to articulate and share information and insights they know are useful to others in their community. That is, the issues of work habits and organization culture are not merely secondary or simply implementation issues as they have been generally regarded in the information management literature [9].

The six characteristics of knowledge that distinguish it from information are described by $\mathrm{Mc}$ Dermott [12]:

Knowledge is a human act.

$\checkmark$ Knowledge belongs to communities.

Knowledge is created in the present moment.

$\checkmark$ Knowledge is the residue of thinking.

Knowledge is created at the boundaries.

Knowledge circulates through communities in many ways. 


\section{THE CHALLENGE TO THE TRADITIONAL METHODS}

People usually consider accounting to be "financial." But this is valid only for the part, going back 700 years, that deals with assets, liabilities and cash flows; it is only a small part of modern accounting. Most of accounting deals with operations rather than with finance, and for operational accounting money is simply a notation and the language in which to express nonmonetary events. Indeed, accounting is being shaken to its roots from being financial and towards becoming operational [13].

Cost management begins with an awareness of what events spawn costs. Only after identifying activities that generate costs can cost management efforts be successful. Management can only control by altering or changing the nature and extent of activities that create costs. The emerging philosophy of activity-based management offers an appropriate framework to identify causes (activities) and effects (costs). Further, cost management is an evolutionary rather than a static process. Over time, costs change for a variety of reasons including inflation, technological innovations, supply and demand effects, and variance in method or application as well as change in process. In addition, innovations in information technology continue to lower the cost of acquiring knowledge about costs. As a consequence, there exist new opportunities to access information that supports increased cost management efforts [14]. forms:

Cost management generally takes one of different

$\checkmark$ Cost Containment,

$\checkmark$ Cost Avoidance,

$\checkmark$ Cost Reduction.

There is the new "transactional" accounting that attempts to relate operations to their expected results. There are attempts to change asset values from historical cost to estimates of expected future returns. Accounting has become the most intellectually challenging area in the field of management, and the most turbulent one. All these new accounting theories aim at returning accounting data into information for management decision making. In other words, they share the goal of computer-based data processing [13].

For management accountants the most important changes in the last few decades have resulted from the rapid movement to more automated and integrated business methods. These new methods damage managerial accounting forms of analysis because they violate the unspoken assumptions in the traditional techniques. For example, traditional production accounting methods assume that direct labor drives most cost, yet it is known that this not happen in factory automation. The new environment violates other assumptions, such as the little recognized fact that standard costing is useful for control purposes in situations with low to medium amounts of variability, but not in situations with high variability or the extremely low variability that is seen in advanced manufacturing technology [15].

Cost or management accounting systems have two major purposes: product costing, and planning and control. Cost accounting techniques for fulfilling these purposes include [16]

Cost / Benefit tests for designing and changing management accounting systems - Elaborate systems are expensive and time consuming, but managers authorize their installation and adaptation only if doing so will sufficiently improve collective operations.

Product costing and control systems that are tailored to underlying operations, not vice versa.

$\checkmark$ Control devices in all product costing systems These systems include responsibility accounting, budgeting, and variance analysis.

\section{$\checkmark \quad$ Various resources of management information in} addition to management accounting systems.

As we have already pointed out, traditional cost systems put most their effort into capturing material and labor costs. All other cost are relegated to overhead accounts. At the same time, management has come to accept overhead as a given and believe that there is not much a manager can do to improve upon this cost area. In the minds of traditionalists, it is the cost of doing business. Therefore, the great majority of effort is put into improving upon labor and material costs. There are two things wrong with this reasoning. First, traditional cost systems rely on far too few elements of production cost to paint a realistic picture. Second, this reliance upon three elements of cost (labor, material, overhead) hides the real opportunities for improvement. In order to rectify this situation, accountants need to restructure their system of reporting costs so that it monitors and controls many more elements and identifies these elements back to correct product and level. This will entail addressing the cost of number of functional activities within manufacturing and beyond. The managers need systems which will report on the activities of Sales, Engineering, Finance and Procurement as they relate to each product [17]. 


\section{THE CHANGES CAUSED BY ACTIVITY - BASED APPLICATIONS}

Activity-based costing changes the traditional view of capacity. In a traditional unit-based system, capacity is defined by the volume of production - the numbers of units produced. In $A B C$, capacity is defined as the ability to perform activities, therefore, every activity identified in $\mathrm{ABC}$ has the potential of going into an excess capacity position. A well-designed $A B C$ system should identify the practical capacity to perform each activity and the use that capacity to generate the costs of performing activity [18].

Activity-Based Costing change process begins with the organization identifying the activities which are being performed by its resources. Resources are defined as any cost creating entity which is utilized to operate an organization's business. People, machines, equipment and even money are just some of the vital resources which a company needs to operate. Knowing how the resources are utilized is at the core of an activity-based system. But knowing how they are used is not always readily apparent and that is why the identification of cost activities begins with the discussion of resource utilization [17].

Activity-Based Costing yields much information about activities and the resources required to perform these activities. Thus $A B C$ is much more than a cost assignment process. ABC supplies the information and activity-based management uses this information in various analyses designed to result in on going improvement. $\mathrm{ABC}$ contributes to cost reduction in marketing and administrative activities as well as improves product costing the concept underlying $\mathrm{ABC}-$ that activities consume resources and products require activities- apply as readily in service organizations as they do in manufacturing organizations [19].

Activity-based management ( $A B M)$ is similar in nature to Business Process Reengineering (BPR) but adds the analysis of the cost management system. ABM consists of two primary viewpoints: a cost view and a process view. Under the cost view, $A B M$ is a cost a cost accounting system (called activity-based costing). It is a system that is used to more accurately determine the full cost analysis of service activities (such as payroll accounting and duplicating), costs of core activities (such as production processes) and costs of products, services, and other cost objets. Under the process view, ABM is used to develop financial and non-financial performance indicators for the output of each activity center. The goal of the cost view is to determine the cost of a product or service, while the goal of the process view is to measure performance. The attractiveness of ABM is that the same information system accomplishes both goals [20].
As defined above, activity-based management is an approach to managing an organization that includes identifying all major operating activities, determining what resources are consumed by each activity identifying how resources are consumed by each activity, and categorizing the activities as either adding value to a product or service or not adding value. Activity-based management is beneficial for both strategic planning and operational decision making because it provides financial and operational performance information at the activity level that is useful for making decisions about business segments, such as product lines, market segments, and customer groups. It also helps managers eliminate waste and inefficiencies and redirect resources to activities that add value to the product or service. Activity-based costing -as mentioned above- is the tool used in an activity-based management environment to assist in assigning activity costs to cost objects for costing and decision making. Activity-based costing helps managers make better pricing decisions, inventory valuations, and profitability decisions [2].

The steps necessary for designing and implementing the process view of activity-based management are outlined below [20]:

1. Develop a clear and succinct mission statement: What is the organization's raison d'être?

2. Determine the core processes and the major cost object: What are the processes that are central to the mission of the organization? What are the items to be ultimately costed?

3. Determine the supporting processes: What are the processes that sustain the core processes, such as certain administrative activities?

4. Form the process teams: What teams should be in place to perform the core and supporting processes? As espoused by reengineering theory, the process teams essentially replace the old function - oriented departments. Each team consists of employees trained (or to be trained) $t$ accomplish the activities within each process?

5. Define the strategic objectives of each process: What are the long - term strategies and goals of each process?

6. Set the major operating objectives of each process: How can the long - term strategies and goals be achieved?

7. Identify the main activities in each process: What are the activities (work to be performed) that encompass each process? In ABM terminology, these are the activity centers. 
8. Develop key performance indicators for each process and activity: How should performance for each process and activity center be measured? The performance indicators may include both financial and non - financial measures.

9. Define the cost drivers for each activity: What is causing resources to be consumed by each activity and cost object?

10. Take steps to ensure the acceptance of the new system: Employees must be oriented and trained to implement the new system and understand its output.

For many managers, the standard approach for improving a business is to benchmark each function or process against the company they think is the best in that function or process. But activity-based management enables companies to leapfrog the best - to become the company everyone else is copying. Activity-based management makes possible dramatic, rather than incremental, improvements [21].

Activities and strategies are closely linked in ABM because strategic choices drive activities. ABM deals with activities and costs that can be changed only gradually, which reflects the long-term perspective taken by $\mathrm{ABM}$ and it concern with strategic issues. Support costs ordinarily can not be changed in one week. Over time, however, changes that occur in a company's production methods, product design, and marketing strategy ultimately affect the company's indirect support costs [22].

A fundamental principle of Total Quality Management is that the business processes which deliver services and products to customers are identified and become the focus for improvement effort. Good management information is needed which can describe and monitor their performance in terms of:

$\checkmark$ reflecting the customer's perspective;

$\checkmark$ identifying the profitability of both products and customers;

$\checkmark$ providing visibility of business processes;

$\checkmark$ explaining or demonstrating cause and effect;

$\checkmark$ reflecting reality;

being predictive;

\section{$\checkmark$ embodying strategy.}

Activity-Based Cost Management is aimed specifically at meeting this need. Its objective is to provide the information needed to improve business processes, and then sustained the improvement, first by enabling management to focus on doing the right things, and second, by providing an approach to doing them right [23].

Activity-Based Cost Management systems have emerged in companies where managers believe that the cost of additional measurements by the ABCM systems are more offset by the benefits the new systems can provide. The managers associates three major benefits of categorizing activities in an ABCM system [24]:

Improved decision making due to more accurate product costs,

$\checkmark$ Improved insights in to managing the activities that lead to traditional fixed costs,

$\checkmark$ Easier access to relevant costs for a wider range of decisions.

Distorted knowledge of product costs makes it difficult for management to know how to best employ the resources available and satisfy its primary responsibility. Unfortunately, although it is relatively easy to prove that a cost system is reporting inaccurate product costs, it is extremely difficult to prove that the firm is suffering because of it. No business decision depends solely on product cost information is commonly used in decisions that rely on a wide range of information. The symptoms of reliance on distorted costs can be used to determine whether the cost system needs redesigning. This approach is advantageous because it is relatively fast and inexpensive. It is not, however, a perfect test. First the symptoms are not always easy to detect, and the inability to detect them does not guarantee that the firm is not suffering. Second, there are several competing explanations for each symptom, and it is not always possible to rule them out. The risk of unfairly blaming the cost system can be reduced by determining whether it suffers from one of the more common design flaws [25].

Supply chains and value chains are the two tools of activity-based management that helps managers better understand their organizations either internal and external operations. 
Figure.1: An Integrated Framework for Activity-Based Management

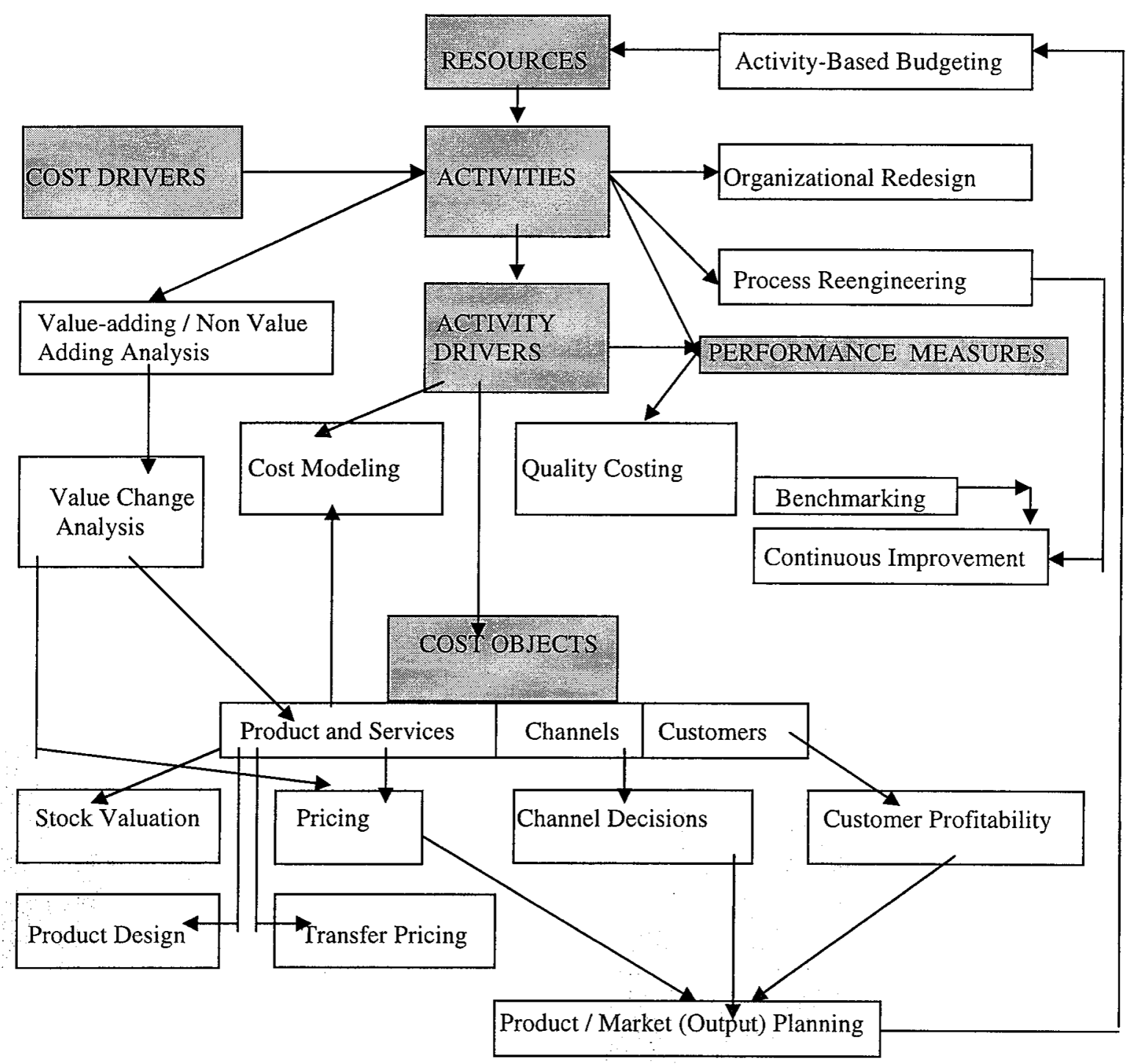

PARTRIDGE, M.; PERREN, L.: "An Intergrated Framework for Activity-Based Decision Making",Management Decision, $36 / 9$, pp.582.

A value chain analysis is essential to determine exactly where in the firm's segment of the chain - from design to distribution - costs can be lowered or customer value enhanced. The value chain framework is a method for breaking down the chain - from basic raw materials to end-user customers - in to strategically relevant activities in order to understand the behavior of costs and the resources of differentiation. Any firm is the typically only one part of the larger set of activities in the value delivery system. Suppliers not only produce and deliver inputs used in a firm's value activities, but they importantly influence the firm's cost or differentiation position as well. Similarly, distribution channels have significant impact on a firm's value activities [26].

A supply chain is an interdependent collection of organizations that supply materials, products, or services to a customer. When managers understand their product's or service's supply chain, they can better understand their organization's role in the total process of creating their product or service and delivering it to customers. Every organization can create a variety of supply chains because of its variety of suppliers and customers [2].

A company can enhance its profitability by understanding not only its own value chain, but also how its value-adding activities fit into its suppliers' and customers' value chain. Working with suppliers and customers across the entire supply chain provides opportunities to reduce the total cost of making a product, even though costs for one activity may be increased. When organizations work cooperatively with others in their supply chain, new processes can be introduced that will reduce the total cost of products or services [2]. 
Managing costs effectively, requires abroad focus, external to the firm. This approach can be analyzed in the strategic cost management framework. This perspective has been termed "value chain" by Porter. The external focus sees each firm in the context of the overall chain of value-creating activities of which it is only a part. Value chain analysis is contrasted with value-added analysis, which starts with payments to suppliers (purchases) and stops with charges to customers (sales), while focusing on maximizing the difference, the value added (sales minus purchases) for the firm [27].

\section{CONLUSION and DISCUSSIONS}

A central argument of this paper concerns the need to understand the relationship between information and knowledge management. Accounting as a system plays an important role in the field of management information. Management needs the true and reliable information before decision making. This information must concern all the activities that the firm is performing. The activity analysis is the lonely way of understanding of what is wrong in the firm and how they can be changed. Thanks this complex and extensive analysis, the knowledge is occurred. The knowledge management is a complex activity rather than to be an art.

The potential benefits of ABCM can be analyzed in advance along two separate dimensions. The first is based on the probability that, in a given application, $\mathrm{ABCM}$ will produce costs or other results that are significantly different from ones that could be generated with more conventional or less costly methods. The $\mathrm{ABCM}$ - generated costs may or may not be "better" or more accurate, but they are different in amount. The second dimension of the model seeks to establish that, given that cost information generated by $A B C M$ is indeed different, management will use it for significant decisions. Managers must regard $\mathrm{ABC}$ information as superior, and the nature of the organization and its competitive, legal and social environments must allow managers to use information freely [28].

Without measurement, management decision making has to be based on intuition, impulse and hunch. Traditional information is based on departments, functions and nominal codes. Modern management thinking has championed the importance of cross departmental initiatives, of core competencies which transcend the confines of strategic business units. Such notions seem to be the way forward, but without sound quantitative activity-based information, we may see a reversion to intuitive decision making [29].

Shields M. \& Young S.M. [30] says that top management must take the initiative in decision making and action to demonstrate to other employees and stake holders that they are serious about improving the competitive position of the firm. Top management must establish strategic goals for cost reduction. These goals should be based on supporting or reinforcing the firm's core competencies and competitive strategy. For example, top management may decide that the best way to reduce cost and to increase both quality and flexibility in the long-term is by exploiting the firm's competence in mechanical, manufacturing, and software engineering by implementing CIM (Computer Integrated Manufacturing) or by looking at the firm as a total of value creating activities. So, the top management may decide to eliminate the activities that are consuming time and labor force or causing cost. This may be named "CostConscious Culture". Top management is responsible to develop this culture through the all firm. The goal of the cost-conscious culture can be summarized as the continuous improvement of quality, time, and cost through innovation.

Systems can become obsolete if they fail to take advantage of technical improvements that permit more efficient data gathering and analysis. Sometimes management changes its strategy and therefore wants to encourage and reward different behavior the cost system doesn't always adapt. The mere presence of symptoms doesn't mean the cost system that the company still using, is obsolete. A product may have inexplicably low profit margins because the cost system is obsolete - or because a competitor has adapted a penetration strategy. It helps to think about the internal and external changes that make a cost system obsolete. Checking for symptoms and looking for changes that may have caused them gives a good indication of the effectiveness of the current system [31].

Increasingly, the financial person will create value in the organization because she or he really understands the operations and is able to develop a customized system that has the highest payoff at the least cost for that organization. That role will require continual involvement in management - level activities and an understanding of the critical success factors in the business, the technology of the business, the nature of outside product, and customer markets. Systems must be kept appropriate and up to date for that environment to meet management objectives [18].

\section{REFERENCES}

[1] INNES, J.; FALCONER, M., Overhead Cost, CIMA Academic Press Inc., 1993, p.81.

[2] NEEDLES, B.E.; POWERS, M.; MILLS, S.K.; ANDERSON, H.R., Managerial Accounting, Fifth 
Edition, Houghton Mifflin Company, Boston, 1999, pp.163-165.

[3] COKINS, G., Activity-Based Cost Management: Making it Work, Mc-Graw Hill Book Company, Boston, 1996, pp.1-42.

[4] ROSS, G.H.B., "Revolution in Management Control", Management Accounting, November 1990, pp.23-27.

[5] BHAT, G.D., "Knowledge Management in Organizations: examining the Interaction Between Technologies, Techniques, and People", Journal of Knowledge Management, Vol.5, No: 1, 2001, pp.68-75.

[6] LIN, B., "Managing in an Information Highway Age: Critical Issues", Industrial Management and Data Systems, Vol: 94, No: 8, 1997, pp.3-7.

[7] ZOIKOCZY, P., Information Technology: an Introduction, Pitman. London, pp.157-158. In Adeoti Adekeye, W.B., "The Importance of Management Information Systems", Library Review, Vol.46, No: 5, 1997, pp.318 - 327.

[8] ADEOTI - ADEKEYE, W.B., "The Importance of Management Information Systems", Library Review, Vol.46, No: 5, 1997, pp.318-327.

[9] LANG, J.C., "Managerial Concerns in Knowledge Management", Journal of Knowledge Management, Vol.5, No: 1, 2001, pp.43-57.

[10] LEAK, C., "Information Systems Framework and Strategy", Industrial Management and Data Systems, Vol.97, No: 3, 1992, pp.86-89.

[11] LANGEMO, M., "Records Management / Word Processing - a Needed Team Afford", Records Management Quarterly, Vol.14, No: 4, 1980, pp.10-14.

[12] McDERMOTT, R, "Why Information Technology Inspired But Cannot Deliver Knowledge Management", California Management Review, Vol:40 No:3, 1999, pp.103-117. In LANG, J.C., "Managerial Concerns in Knowledge Management", Journal of Knowledge Management, Vol.5, No: 1, 2001, pp.43-57.

[13] DRUCKER, P.F., „Be Data Literate - Know What to Know", The Wall Street Journal, $\left(1^{\text {st }}\right.$ December, 1992, p.14.

[14] GROTH, J.C.; KINNEY, M.R., "Cost Management and Value Creation”, Management Decision, Vol.32, No: 4, 1994, pp.52-57.

[15] SAKURAI, M. ; SCARBROUGH, D.P., Japanese Cost Management, Crisp Publications, California, 1992, p.13.

[16] FOSTER, G.; HORNGREN, C.T., "Cost Accounting and Cost Management in a JIT Environment", Journal of Cost Management, Winter 1998, p.4.
[17] GRIECO, P.L.; PILACHOWSKI, M.JR., Activity-Based Costing: The Key To The World Class Performance, PT Publications, Florida, 1995, pp.13-98.

[18] KING, A.M., "The Current Status Of Activity-Based Costing: An Interview With Robin Cooper and Robert $S$. Kaplan", Management Accounting, Vol.LXXIII, No: 3, 1991, p.26.

[19] RAYBURN, G.L., Cost Accounting: Using a Cost Management Approach, Times Mirror Higher Education Group, Sydney, 1996, p.131.

[20] TRUSSEL, M.J.; BITNER, L.N., "Strategic Cost Management: an Activity-Based Management Approach", Management Decision, Vol.36, No: 7, 1998, pp.441-447.

[21] NESS, J.A.; CUCUZZA, T.G,, "Tapping the Full Potential of $A B C$ ", Harvard Business Review, JulyAugust 1995, pp.130-138.

[22] ROTCH, W., "Activity-Based Costing in Service Industries", Journal of Cost Management, Summer 1990, p.5.

[23] CLARK P.; BELLIS, J.R., "Activity Based Cost Management In The Management Of Change", The TQM Magazine, Vol.8, No: 2, 1996, pp.43-48.

[24] COOPER, R., "Cost Classification in Unit-Based and Activity-Based Manufacturing Cost Systems", Journal of Cost Management, Fall 1990, p.10.

[25] COOPER, R., "Cost Management Concepts and Principles: Does Your Company Need a New Cost System?", Journal of Cost Management, Spring 1987, pp.48-49.

[26] SHANK, J.K.; GOVINDARAJAN, V., "Strategic Cost Management and The Value Chain", Journal of Cost Management, Winter 1992, p.7

[27] SHANK, J.K.; GOVINDARAJAN, V. "Strategic Cost Analysis of Technological Investments", Sloan Management Review, Fall 1992, pp.47-49.

[28] ESTRIN, T.L.; KANTOR, J.; ALBERS, D., "Is $A B C$ Suitable for Your Company?", Management Accounting, April 1994, p.40.

[29] PARTRIDGE, M.; PERREN, L. "An Integrated Framework for Activity- Based Decision Making", Management Decision, Vol.36, No: 9, 1998, pp.580-588.

[30] SHIELDS, M.; YOUNG, S.M., "Effective Long-Term Cost Reduction: A Strategic Perspective", Journal of Cost Management, Spring 1992, p.23.

[31] COOPER, R., "You Need a Cost System When", Harvard Business Review, January - February 1989, p.82. 